\title{
Overvoltages on Power Filters under Energizing Industrial Power System Transformer
}

\author{
Yuriy Varetsky ${ }^{*}$ \\ Lviv Polytechnic National University, 12 Stepana Bandery St., Lviv, 79013, Ukraine
}

Received: October 18, 2020. Revised: November 17, 2020. Accepted: November 24, 2020.

() 2020 The Author. Published by Lviv Polytechnic National University.

\begin{abstract}
The practice of operating industrial power supply systems containing filter circuits has shown that filter tuning can have a significant impact on filter performance. On the basis of simulations of a real power supply system carried out by the Matlab / Simulink package, the results of a study of the impact of filter manufacturing tolerances on the filter transients under transformer energizing are presented. The most severe transients are observed for filter circuits in the power supply systems of electric arc furnaces due to frequently repeated operating energizing furnace transformers. This article summarizes the analysis of overvoltages on capacitors and reactors for various configurations of the filter circuit, arising during energizing the arc furnace transformer, taking into account the possible detuning of the filters.
\end{abstract}

Keywords: power filter; capacitor bank; filter reactor; filter tuning; switching transients.

\section{Introduction}

The operation of the selected configuration of a filter circuit (FC), consisting of several filters, is determined by the resulting impedance of the industrial system as a whole. Each change in this impedance affects the efficiency of harmonic suppression in the power supply system. The practice of designing filters assumes that the parameters of its capacitors and reactors are predetermined. Although there are many types of filters, industrial power systems typically use either single tuned (LC-type) or damped (C-type) filters. The filter impedance at the tuned frequency is much lower than the system impedance. One of the problems when using a harmonic filter is the reasonable choice of the tuning frequency. Detuning a filter can significantly change the filter impedance at the required filtered frequency and reduce filter efficiency. Capacitors and filter reactors have certain manufacturing tolerances and the filter tuning must take this into account. It is important to understand that the choice of the filter resonant point is dependent on changes in reactor inductance and capacitor capacitance of the filter caused by manufacturing tolerances and temperature fluctuations. Filter design addresses this problem by tuning individual filters away from resonant harmonics, typically about 5 percent below the nominal resonant frequency. Improperly selected filter resonant point can cause overloading the filter in some power system operating configurations. The selected values of the inductance and capacitance for the filter determine the nature of the impedance-frequency response: for the harmonic below the resonant one, the filter represents the capacitive impedance, and for all harmonics of a higher order - the inductive impedance.

Individual filters in a selected FC are connected to the power grid through an individual or common circuit breaker. The operation of filters in an industrial environment has shown that changes in the parameters of the capacitor and reactor of a filter may occur over time due to deterioration of their insulation, which results in a change in the resulting power supply system impedance-frequency response [1]-[3]. The consequences of such situations are damage of the filter reactors and filter capacitors as a result of overloads and overvoltages arising during steady or transient operating conditions.

${ }^{*}$ Corresponding author. Email address: j.varetsky@gmail.com

This paper should be cited as: Y. Varetsky. Overvoltages on power filters under energizing industrial power system transformer. Energy Engineering Control Systems, 2020, Vol. 6, No. 2, pp. 97 - 103. https://doi.org/10.23939/jeecs2020.02.097 
The article presents an analysis of the filter tuning impact on the overvoltage levels on individual filters during operating energizing an electric arc furnace (EAF) transformer in the power supply system by the example of the filter circuit of a Static VAr Compensator (SVC). As the experience of operating such systems has shown, the EAF transformers are switched on 30-40 times per day. Therefore, the transient overvoltages are an important factor in the sizing SVC filters [4]. Also, the impact of a damped C-type filter on the nature of transients, when changing the filter tuning was investigated.

\section{Power filter tuning}

Filter tuning consists in choosing the appropriate series resonant frequency for the individual branches of a FC in order to reduce the voltage distortion level in the power supply system and prevent possible parallel resonances.

The practice of operating various configurations of FC has shown that the tuning of individual filters should be performed at a frequency slightly lower than the required exact resonant frequency. Such tuning based on a lower frequency value is carried out due to the fact that with possible changes in the filter parameters, the filter reactance at the frequency of a filtered harmonic will be inductive, which will prevent possible parallel resonance. The degree of the filter detuning is primarily determined by manufacturing tolerances of the filter components. In practice, a parameter $n_{D}$ is used that is the order of the tuning frequency of a single-branch passive filter relative to the fundamental frequency of the power system:

$$
n_{D}=(\omega \sqrt{L C})^{-1} .
$$

Assuming constant power system frequency $\omega$, it can be seen that the capacitor and reactor manufacturing tolerances cause filter detuning between the next values in relation to the required tuning frequencies $n_{F}$ :

$$
n_{F}[\sqrt{(1+\Delta L)(1+\Delta C)}]^{-1} \leq n_{D} \leq n_{F}[\sqrt{(1-\Delta L)(1-\Delta C)}]^{-1},
$$

where $\Delta L, \Delta C$ are inductance and capacitance variations, p.u.; $n_{F}$ is fine relative filter resonant frequency $(F=2,3,5)$.

When designing individual filters of the $\mathrm{FC}$, the inductance tolerance of the filter reactor is assumed to be within $-5 \%$ to $+5 \%$ [5], [6]. In the case of filter capacitor banks the capacitance tolerance is in the range of $-5 \% \ldots+10 \%$ [6], [7]. Then the relative tuning frequency is in the range:

$$
0,93 \cdot n_{F} \leq n_{D} \leq 1,05 \cdot n_{F}
$$

In engineering practice, the designed filters of the FC system are never tuned to the frequency of the filtered harmonic, as this may lead to a shift of the resonance points of the power system impedance-frequency characteristic due to variations of the FC parameters [8]. If, as a result of this displacement, one of the resonant frequencies of the filter system is higher than the frequency of the filtered harmonic, the filter of this harmonic may be overloaded due to the parallel resonance at this harmonic in the power supply system. The permissible current and voltage overload coefficients of filter capacitors in relation to the RMS rated values are $130 \%$ and $110 \%$, respectively [5]-[7]. The frequency dependence of the system impedance determines the filtering quality, therefore, any filter detuning or the use of filter damping leads to a decline in the harmonic filtering efficiency.

Variations in filter capacitance or inductance have a greater impact on the detuning of the higher order filter than the detuning of the lower order filter. For example, the relation (4) reflects the impact of inductance drift on the degree of the resonant frequency deviation:

$$
\Delta \omega_{D} \approx \frac{d \omega_{D}}{d L} \Delta L=d\left(\frac{1}{\sqrt{L C}}\right) \frac{\Delta L}{d L}=-\frac{\Delta L}{2 L} \omega_{D},
$$

where $\omega_{D}=n_{D} \cdot \omega$.

As a consequence, due to manufacturing deviations of the filter parameters from their nominal values, residual harmonic currents will be observed in the resulting current of the power supply system. In some cases, during field measurements, overloads of filter capacitors and reactors were observed [3] due to an improper filter tuning. This can be avoided by carefully analyzing the system and choosing well-reasoned decisions. 
Field studies have shown that filter detuning also has a significant effect on the level of transient overvoltages across capacitors and reactors of the filter when parallel transformers are energized [1]. This problem is of particular concern in EAF power supply systems.

\section{Filter circuit description}

The examined industrial power system consists of an EAF, powered by a TP furnace transformer with a rated power of 50 MVA and a SVC based on two basic components: TCR (Thyristor Controlled Reactor) and FC (Filter Circuit), shown in the Fig.1.

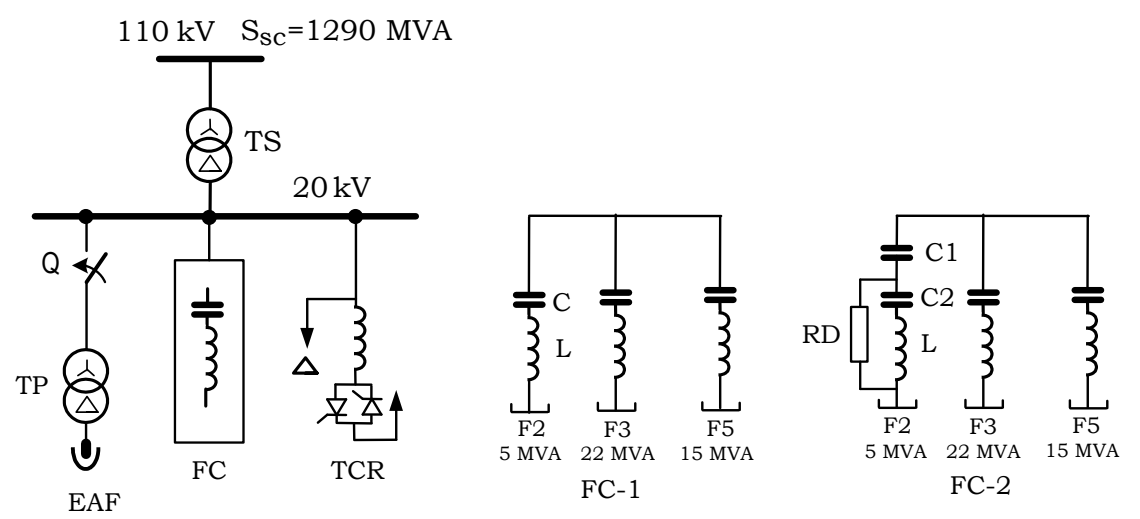

Fig.1. One line diagram of the industrial power supply system.

The $20 \mathrm{kV}$ equipment of the medium voltage system is supplied from the $110 \mathrm{kV}$ network through the $80 \mathrm{MVA}$ system transformer TS. In the course of the study, two possible configurations filter circuits were analyzed: FC-1, consisting of three simple LC filters of the F2, F3, and F5 types with power ratings of 5, 22, and 15 MVA, respectively; and FC-2, consisting of a C-type filter F2 jointly with F3 and F5 LC type filters with the same power ratings as in the previous configuration. Tables 1 and 2 show the filter parameters in the considered configurations with the design tuning (actual filter tuning) and fine tuning of the filters.

Table 1. Parameters of LC-type filters

\begin{tabular}{|c|c|c|c|c|c|}
\hline \multicolumn{7}{|c|}{ Design tuning } \\
\hline \hline Filter & Tuning point & Capacitance, $\mathrm{C}[\mu \mathrm{F}]$ & Inductance, $\mathrm{L}[\mathrm{mH}]$ & Loss resistance, $\mathrm{R}[\Omega]$ & $\mathrm{I}_{\text {nom }},[\mathrm{A}]$ \\
\hline F2 & 1.86 & 28.30 & 103.59 & 0.27 & 144 \\
\hline F3 & 2.79 & 152.01 & 8.57 & 0.07 & 632 \\
\hline F5 & 4.65 & 113.90 & 4.12 & 0.04 & 433 \\
\hline \multicolumn{7}{|c|}{ Fine tuning } & 0.24 & 632 \\
\hline \hline F2 & 2.0 & 155.05 & 7.86 & 0.06 & 433 \\
\hline F3 & 3.0 & 114.64 & 3.54 & 0.03 & \\
\hline
\end{tabular}

Table 2. Parameters of F2 C-type filter

\begin{tabular}{|c|c|c|c|c|c|}
\hline \multicolumn{7}{|c|}{ Design tuning } \\
\hline \hline Tuning point & Capacitance $\mathrm{C} 1[\mu \mathrm{F}]$ & Capacitance, $\mathrm{C} 2[\mu \mathrm{F}]$ & Inductance, $\mathrm{L}[\mathrm{mH}]$ & Resistance, $\mathrm{RD}[\Omega]$ & $\mathrm{I}_{\text {nom }},[\mathrm{A}]$ \\
\hline 1.86 & 39.79 & 97.86 & 103.59 & 107.53 & 144 \\
\hline \multicolumn{5}{|c|}{ Fine tuning } \\
\hline \hline 2.00 & 39.79 & 119.37 & 84.94 & 100.00 & 144 \\
\hline
\end{tabular}

Figure 2 shows the system impedance-frequency response for the compared filter tuning frequencies, where appropriate changes in the impedance value for the harmonics to be filtered in the power supply system can be observed. 


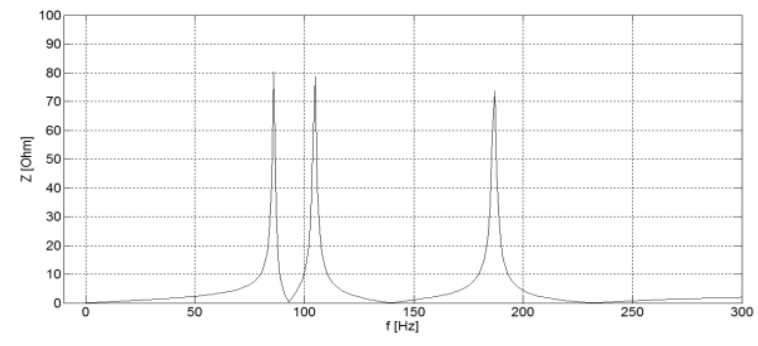

Design tuning

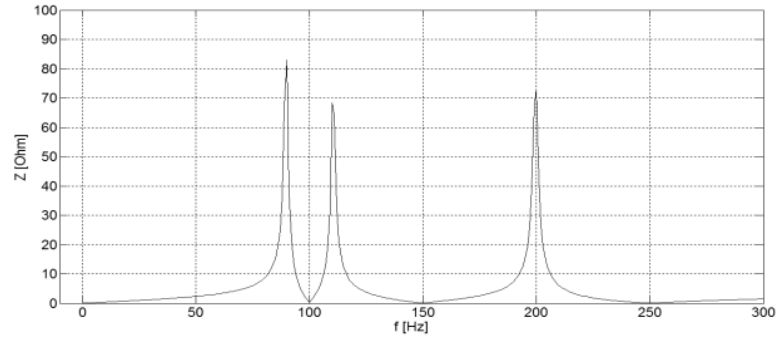

Fine tuning

Fig.2. Frequency responses of the examined power system.

As can be seen from Fig.2, comparison of impedance-frequency characteristics shows slightly higher impedance values for the harmonic currents to be filtered in the case of the filter design tuning. This will lead to some decrease in the efficiency of the filters.

\section{Results of transient simulations under transformer energizing}

The purpose of the simulation tests was to determine the effect of the change in tuning of the filtering unit, caused by the change in the inductance tolerance of the filter reactor and the capacitance of the capacitor bank on the values of the maximum amplitudes of transient voltages and currents in the filter circuits operating in a specific FC circuit connection topology. The tests were carried out with a typical switching in an arc furnace power system energizing the furnace transformer, which is the most severe operational switching.

During the operation of the compensation system, its various configurations are possible; hence the impact of the topology of FC and tuning accuracy on the amplitudes of transient voltages and currents on the reactor and the capacitor of the individual filters was examined.

Filter circuit consists of three simple LC filters - F2, F3, and F5. Figure 3 shows sample waveforms of the transient currents and voltages for the most loaded phase of the second harmonic LC-type filter in the FC-1 configuration, obtained for design and fine tuning, when energizing the furnace transformer TP. Energizing the transformer causes a significant increase in the second harmonic transient oscillations in the F2 filter unit.
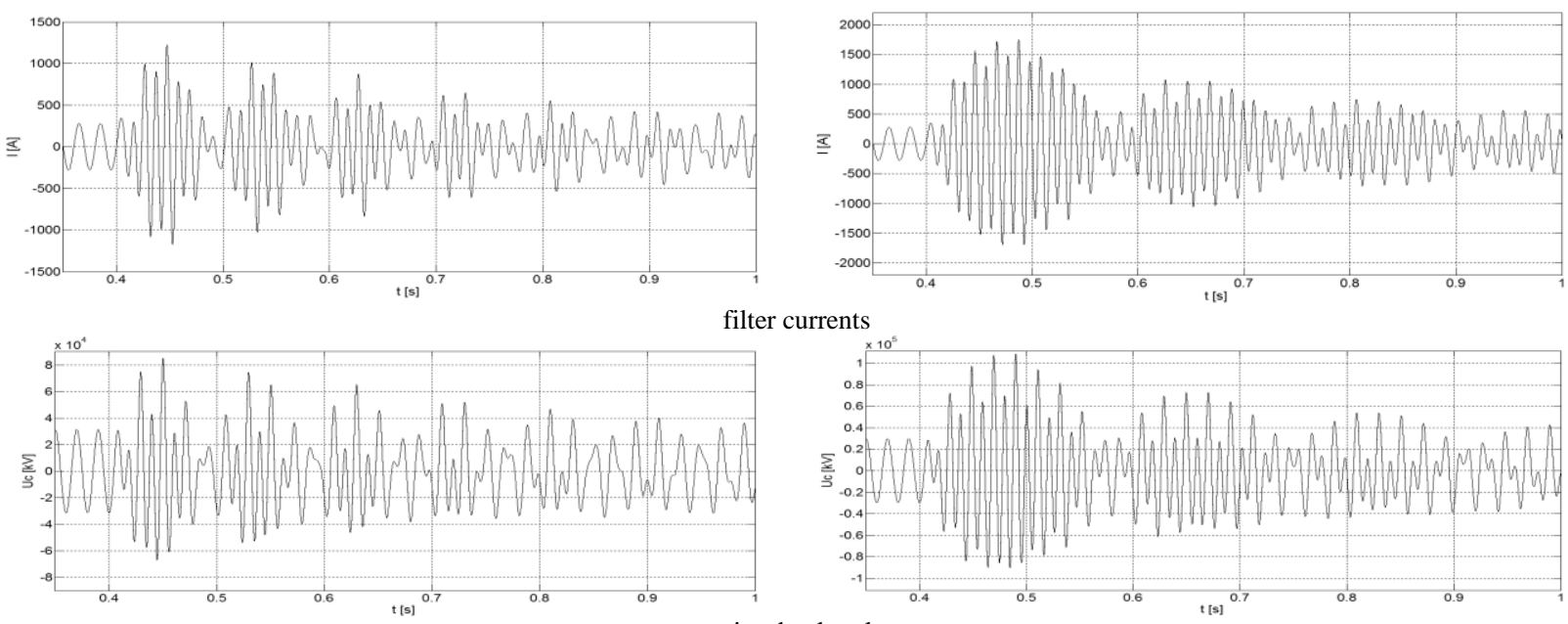

capacitor bank voltages
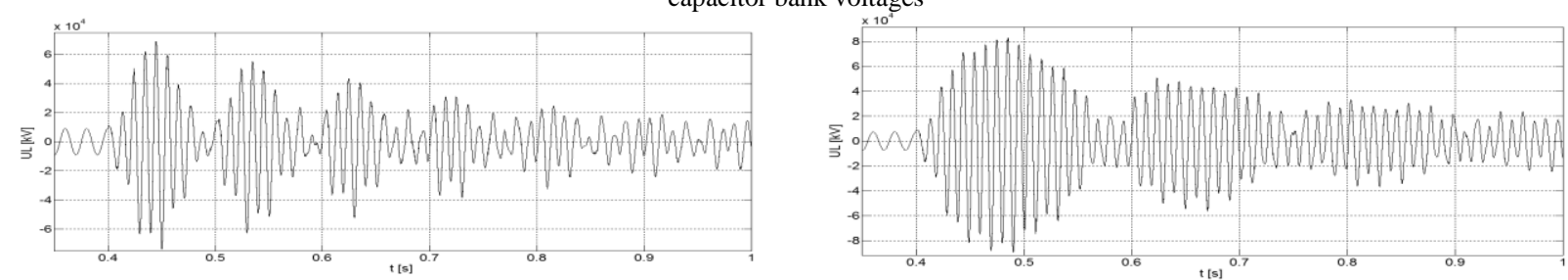

design tuning fine tuning
Fig.3. Transient currents and voltages on the F-2 LC type filter during energizing the EAF transformer.

filter reactor voltages 
As can be seen from the oscillograms of the examined power supply system, deviations of the filter parameters cause changes in the transient currents and voltages. Fine tuning the filters of the FC to the resonant frequency leads to a significant increase in the amplitudes of transient currents and voltages in the filter circuits. The nature of the registered switching overvoltages on the capacitors and filter reactors and their amplitudes directly depend on the frequency of the filter tuning.

Table 3 shows the maximum peaks of the transient current and voltages in the FC-1 unit, obtained under energizing the EAF transformer TP.

Table 3. Transient current and voltages peaks on the filters during switching on the transformer

\begin{tabular}{|c|c|c|c|c|c|}
\hline \multicolumn{6}{|c|}{ Design tuning } \\
\hline \multirow{2}{*}{ Filtr } & \multirow{2}{*}{\multicolumn{2}{|c|}{ Current peaks }} & & \multicolumn{2}{|c|}{ Voltage peaks } \\
\hline & & & & Capacitor bank & Reactor \\
\hline \multirow{2}{*}{$\mathrm{F} 2$} & $\mathrm{kA}$ & 1.22 & $\mathrm{kV}$ & 85.01 & 737.57 \\
\hline & p.u. ${ }^{(*)}$ & 5.99 & p.u. ${ }^{(*)}$ & 3.71 & 11.10 \\
\hline \multirow{2}{*}{ F3 } & $\mathrm{kA}$ & 2.13 & $\mathrm{kV}$ & 31.20 & 12.04 \\
\hline & p.u..$^{(*)}$ & 2.38 & p.u. ${ }^{(*)}$ & 1.67 & 5.01 \\
\hline \multirow{2}{*}{ F5 } & $\mathrm{kA}$ & 1.97 & $\mathrm{kV}$ & 28.15 & 8.59 \\
\hline & p.u. ${ }^{(*)}$ & 3.22 & p.u..$^{(*)}$ & 1.65 & 10.87 \\
\hline \multicolumn{6}{|c|}{ Fine tuning } \\
\hline \multirow{2}{*}{$\mathrm{F} 2$} & $\mathrm{kA}$ & 1.75 & $\mathrm{kV}$ & 108.57 & 88.98 \\
\hline & p.u..$^{(*)}$ & 8.61 & p.u. ${ }^{(*)}$ & 4.73 & 13.42 \\
\hline \multirow{2}{*}{ F3 } & $\mathrm{kA}$ & 2.39 & $\mathrm{kV} \mathrm{w}$ & 33.49 & 14.07 \\
\hline & p.u. ${ }^{(*)}$ & 2.68 & p.u..$^{(*)}$ & 1.79 & 5.85 \\
\hline \multirow{2}{*}{ F5 } & $\mathrm{kA}$ & 2.48 & $\mathrm{kV}$ & 31.71 & 8.70 \\
\hline & p.u. ${ }^{(*)}$ & 4.06 & p.u. ${ }^{(*)}$ & 1.85 & 11.01 \\
\hline
\end{tabular}

${ }^{(*)}$ Base value - the magnitude of the rated current and the magnitude of the operating voltage of the filter reactor and the filter capacitor bank at the rated voltage on the bus.

The study results showed that higher peaks of transient currents and voltages on the filter components are observed with a full set of filters than in the case of a single filter in the FC unit. This issue is typical for any filter tuning conditions. As noted, filter detuning can result in significant changes in filter transient currents and voltages during the transformer energization. Figure 4 shows the maximum voltage peaks $\left(U_{\text {Cpeak }}\right.$ and $\left.U_{\text {Rpeak }}\right)$ across the capacitor and the reactor bank of the second filter F2 during energizing furnace transformer versus relative filter tuning.

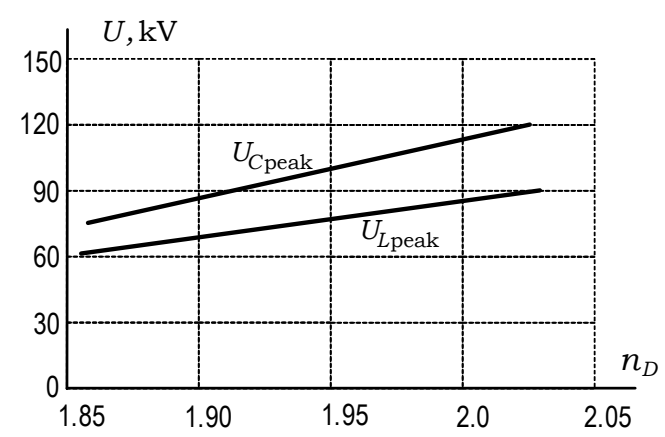

Fig.4. Maximum F2 filter voltage peaks versus relative filter tuning.

Filter circuit consists of C-type filter F2 and two simple LC-type filters - F3 and F5. Mitigation of the transformer energization inrush current effect on the filter equipment can be achieved by using a damping in the FC unit. The most efficient solution is to apply C-type filter within FC configuration, which is characterized by low fundamental frequency losses [9]. Figure 5 presents the waveforms of the currents and voltages of the most loaded phase of the F2 C-type filter, tuned exactly to the resonance frequency, obtained under energizing the TP transformer. 

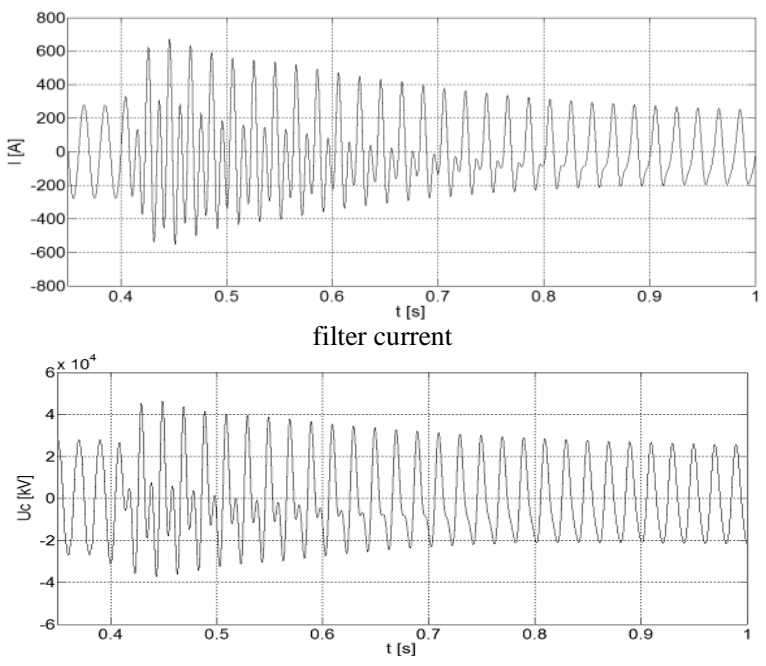

capacitor bank voltage

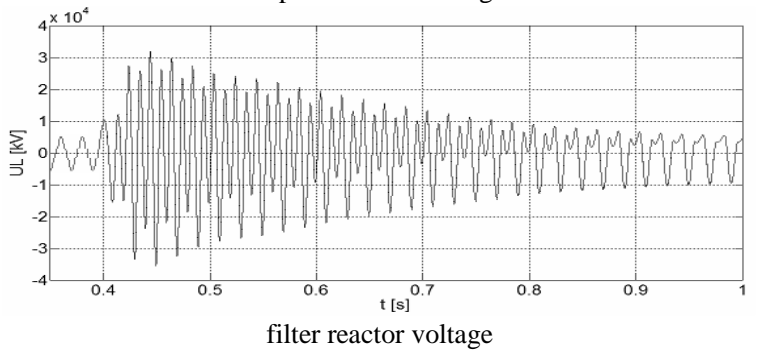

Fig.5. Transient current and voltages on the F-2 C-type fine tuned filter.

From the above oscillograms it can be seen that the use of a damped C-type filter, even with fine tuning of all installed filters in the FC-2 unit, significantly mitigates the amplitudes of transient currents and voltages, and also reduces the duration of the transient compared to the configuration of a FC-1 unit consisting of simple LC-type filters.

The study showed that filter tuning has a significantly smaller impact on the amplitudes of transient overvoltages and currents compared to the FC unit based only on simple LC-type filters. Exact resonant tuning filters leads to slightly higher amplitudes of transient overvoltages and currents than in the case of the design tuning, as it can be observed in Table 4.

Table 4. Transient current and voltages peaks on the filters during switching on the transformer.

\begin{tabular}{|c|c|c|c|c|c|}
\hline \multicolumn{6}{|c|}{ Design tuning } \\
\hline \multirow{2}{*}{ Filtr } & \multirow{2}{*}{\multicolumn{2}{|c|}{ Current peaks }} & & \multicolumn{2}{|c|}{ Voltage peaks } \\
\hline & & & & Capacitor bank & Reactor \\
\hline \multirow{2}{*}{ F-2(C-type) } & $\mathrm{kA}$ & 0.67 & $\mathrm{kV}$ & 446.31 & 35.56 \\
\hline & p.u..$^{(*)}$ & 3.30 & p.u. ${ }^{(*)}$ & 2.02 & 5.36 \\
\hline \multirow{2}{*}{ F-3 } & $\mathrm{kA}$ & 2.63 & $\mathrm{kV}$ & 35.67 & 11,69 \\
\hline & p.u. ${ }^{(*)}$ & 2.95 & p.u. ${ }^{(*)}$ & 1.91 & 4.86 \\
\hline \multirow{2}{*}{ F-5 } & $\mathrm{kA}$ & 1.41 & $\mathrm{kV}$ & 28.42 & 4.18 \\
\hline & p.u. ${ }^{(*)}$ & 3.34 & p.u. ${ }^{(*)}$ & 1.67 & 1.74 \\
\hline \multicolumn{6}{|c|}{ Fine tuning } \\
\hline \multirow{2}{*}{ F-2(C-type) } & $\mathrm{kA}$ & 0.77 & $\mathrm{kV}$ & 46,37 & 35.62 \\
\hline & p.u. ${ }^{(*)}$ & 3.77 & p.u. ${ }^{(*)}$ & 2.02 & 5.38 \\
\hline \multirow{2}{*}{ F-3 } & $\mathrm{kA}$ & 2.27 & $\mathrm{kV}$ & 34.25 & 12.09 \\
\hline & p.u. ${ }^{(*)}$ & 2.55 & p.u. ${ }^{(*)}$ & 1.83 & 5.03 \\
\hline \multirow{2}{*}{ F-5 } & $\mathrm{kA}$ & 1.86 & $\mathrm{kV}$ & 26.52 & 5.46 \\
\hline & p.u. ${ }^{(*)}$ & 3.04 & p.u..$^{(*)}$ & 1.43 & 6.91 \\
\hline
\end{tabular}

${ }^{(*)} \mathrm{B}$ ase value - the magnitude of the rated current and the magnitude of the operating voltage of the filter reactor and the filter capacitor bank at the rated voltage on the bus. 


\title{
5. Conclusion
}

The article presents the results of a study of the effect of energizing a transformer on transients in the filter circuit of the EAF power supply system. The presence of harmonics in the transformer inrush current can excite increasing voltages and currents in the filter circuit at the resonant harmonics.

Deviation of filter reactor and capacitor bank parameters, caused by manufacturing tolerances, significantly affects the transient voltage magnitudes on filter capacitors and reactors. This can cause filtering equipment failure and may require higher ratings of the capacitor banks and reactor than are selected for steady state operating conditions.

The use of a C-type damped filter in an FC configuration significantly mitigates the magnitudes of transient currents and transient voltages in the FC filters, and also reduces the risk of increasing amplitudes of transient currents and transient voltages when the filter tuning is changed.

\section{References}

[1] Varetsky Y., Gajdzica M. (2015) Energizing arc furnace transformer in power grid involving harmonic filter installation. Przegląd Elektrotechniczny nr 4, s. 64 - 69. DOI: 10.15199/48.2015.04.17.(in Polish)

[2] Simpson Ronald H. (2005) Misapplication of power capacitors in distribution systems with nonlinear loads - three case histories. IEEE Transactions on Industry Applications, vol. 41, no. 1, January/February, pp. 134 - 143.

[3] Witte J.F. et al: (1994) Damaging long-term overvoltages on industrial capacitor banks due to transformer energizing inrush current. IEEE Trans. on Industry Applications, vol.30, no.4, pp. 1107-1115.

[4] Varetsky Y., Gajdzica M. (2020) The procedure for selecting the ratings of capacitor banks and reactors of the filtering systems. Przeglad Elektrotechniczny, nr 96(3), pp. 77-81. DOI: 10.15199/48.2020.03.19.(in Polish)

[5] IEEE Std. P57.16/d7 - 2010. Draft Standard Requirements, Terminology, and Test Code for Dry Type Air Core Series Connected Reactors, New York, IEEE, 2010.

[6] IEEE Guide for Application and Specification of Harmonic Filters, IEEE Std 1531-2003.

[7] IEEE Std. 18-2012, Standard for Shunt Power Capacitors, New York, IEEE, 2013.

[8] Varetsky Y. (2001) Exploitative characteristics of SVC filter circuits. Proc. of 6-th Int. Conf. Electrical power quality and utilization, Cracow, pp. $297-302$.

[9] Mohamed I. F., Shady H.E., Aleem A., Ibrahim A. M., Zobaa A. F. (2014) Optimal Sizing of C-Type Passive Filters under Non-Sinusoidal Conditions, Energy Technology \& Policy: An Open Acess Journal, Vol. 1, p.35-44. DOI 10.1080/23317000.2014.969453

\section{Перенапруги на силових фільтрах під час увімкнення трансформатора в промисловій системі електропостачання}

\author{
Юрій Варецький \\ Національний університет “Львівська політехніка”,вул. Степана Бандери, 12, м. Львів, 79013, Україна
}

\section{Анотація}

Практика експлуатації промислових систем електропостачання, які мають у своєму складі силові фільтри, показала, що налаштування фільтра може мати значний вплив на робочі характеристики фільтра. На основі моделювання реальної системи електропостачання, здійсненого за допомогою пакету Matlab/ Simulink, у статті представлено результати дослідження впливу технологічних допусків параметрів фільтрів на характер перехідних процесів у колі фільтра під час увімкнень трансформатора. Виконано аналіз перенапруг на конденсаторах i peакторах різних конфігурацій фільтрового комплексу, які виникають під час експлуатаційних увімкнень трансформатора, з урахуванням можливого розлаштування фільтрів. Відхилення параметрів реактора та конденсатора фільтра, спричинене технологічними допусками їх виготовлення, суттєво впливає на величини перехідної напруги на конденсаторах та реакторах фільтрів. Це може призвести до виходу з ладу обладнання фільтра та вимагати застосування батарей конденсаторів та реактора 3 вищими номінальними параметрами, ніж це необхідно для усталеного режиму роботи. В результаті досліджень показано, що використання демпфованого фільтра типу “C” у конфігурації фільтрового комплексу значно зменшує амплітуди перехідних струмів та напруг на обладнанні фільтра, а також зменшує ризик збільшення амплітуд перехідних струмів та перехідних напруг внаслідок зміни налаштування фільтра.

Ключові слова: силовий фільтр; конденсаторна батарея; фільтровий реактор; налаштування фільтра; комутаційні перехідні процеси. 